\title{
Bacterias de suelo solubilizadoras de fosfato y su interacción con plantas de interés agronómico.
}

\author{
Taurian, Tania ${ }^{1}$ \\ ${ }^{1}$ Universidad Nacional de Rio Cuarto, Facultad de Ciencias Exactas, Físico-Químicas y Naturales, \\ Departamento de Ciencias Naturales. \\ Conferencia dictada en el marco de la XI Reunión Nacional Científico-Técnica de Biología de Suelos. \\ Corrientes (Argentina)- Octubre de 2017
}

Las bacterias solubilizadoras de fosfato constituyen una comunidad heterogénea que comparten la capacidad de solubilizar fuentes insolubles de fosfato dejando disponible el $\mathrm{P}$ para su propio metabolismo y para los organismos que comparten su nicho ecológico. En el ecosistema rizosférico, este fenómeno se traduce en un aporte directo de $\mathrm{P}$ a las plantas con el consecuente incremento en el crecimiento y productividad de los cultivos. En suelos que presentan un déficit de este nutriente, este grupo de bacterias adquiere gran relevancia. La formulación y aplicación a campo de biofertilizantes a base de bacterias solubilizadoras de fosfato es una alternativa más eficiente y económica frente a la actual aplicación de fertilizantes químicos. En los suelos agrícolas de la provincia de Córdoba, zona principal de producción manisera argentina, se han reportado niveles bajos de P. En las leguminosas como el maní, el P constituye un nutriente aún más esencial debido a la elevada demanda energética que presenta el proceso de FBN que se realiza en sus nódulos radicales en simbiosis con los "rizobios". A partir de aislamientos bacterianos de tejidos y rizósfera de plantas de maní de suelos maniseros de Córdoba, se generó en el laboratorio una colección de bacterias con capacidad solubilizadora de fosfato. Esta colección constituyó la base de los estudios abocados a este importante grupo de bacterias promotoras del crecimiento vegetal tendientes a conocer los mecanismos involucrados en la solubilización de fosfato mediante determinaciones bioquímicas e identificación de genes, comprender el diálogo molecular de estas bacterias con las plantas, analizar el efecto de su inoculación en plantas de interés agrícola a distintas escalas y comprender el efecto de prácticas agrícolas sobre esta comunidad bacteriana. Los estudios realizados indican que en los suelos agrícolas de la zona manisera de Córdoba existe una fuente potencial de bacterias solubilizadoras de fosfato (BSP) representadas en su mayoría por géneros pertenecientes a las Enterobacterias, y en menor medida a bacterias gram positivas y a Pseudomonas. Estas bacterias nativas de maní constituyen una fuente potencial para su empleo como biofertilizante ya que demuestran promover el crecimiento de maní aumentando el contenido de $\mathrm{P}$ en sus tejidos aéreos. El principal mecanismo involucrado en su capacidad solubilizadora de fosfato es la producción de ácido glucónico el cual es producto de la oxidación directa de la glucosa por actividad de la holenzima GDH-PQQ. Las bacterias analizadas demostraron producir diversas cantidades de ácido glucónico, sin que exista correlación entre dichos valores y los niveles de P solubilizado por las mismas. Sin embargo, la mutación de uno de los genes $p q q$ en una de las cepas de la colección y, el incremento de la expresión de estos genes en condiciones de deficiencia de P, confirmó que esta oxidación es el principal mecanismo para la obtención de P soluble. Sumado a esto, se llevaron a cabo estudios tendientes a profundizar el conocimiento de la interacción de las BSP con las plantas. Así, fue posible observar que los exudados radiculares producen cambios en las expresiones de genes involucrados con este fenotipo. Los ensayos en planta permitieron sugerir que la misma responde a la inoculación con una BSP produciendo un estallido oxidativo en etapas tempranas de la interacción. A partir de estudios de inoculación con una cepa de la colección no productora de PQQ, se observó que la respuesta oxidativa era más temprana y exacerbada respecto a las plantas inoculadas con la cepa salvaje lo cual sugiere que este cofactor podría modular dicha respuesta. En ensayos ex planta con la mutante PQQ- se determinó que el cofactor modula la respuesta oxidativa, probablemente modificando la actividad de las enzimas del sistema antioxidante. A ello se suma que en plantas inoculadas con la cepa PQQ- el número de células que colonizaban las raíces de las plantas era menor, sugiriendo que el cofactor podría tener un rol en la colonización endofítica. Esta capacidad constituye un rasgo interesante ya que otorga ventaja para persistencia de estas bacterias en los sistemas agrícolas. A los efectos de profundizar los conocimientos de la capacidad infectiva de las BSP en los tejidos, se encuentran en marcha estudios tendientes a determinar las propiedades de movilidad de las bacterias y su relación con la colonización endofítica. Las actividades agrícolas actuales incluyen la aplicación de pesticidas y fertilizantes para el control de malezas y fitopatógenos y el aporte de nutrientes esenciales, respectivamente. El empleo intensivo de los mismos redunda en muchos casos, negativamente en las comunidades microbianas del suelo asociadas a las plantas. La 
evaluación del efecto de la aplicación de pesticidas en los suelos maniseros de la provincia de Córdoba sobre la abundancia y diversidad genética de bacterias solubilizadoras de fosfato indicó un cambio en la estructura determinándose un aumento de la diversidad genética de dicha población y modificación en la frecuencia del gen bacteriano $p q q E$ pero no en la abundancia de las mismas. En ensayos realizados a campo se determinó que el empleo de BSP en conjunto con los fertilizantes fosforados, produce un incremento en el rendimiento de maní. Un aspecto importante de considerar en la búsqueda de un potencial biofertilizante es su capacidad de persistencia en el sistema. Esto constituye un desafío interesante debido a que el microorganismo no solo debe ser capaz de sobrevivir sino también de mantener su propiedad benéfica. Así, el análisis de la capacidad de promover otras plantas de interés agrícolas tales como el maíz, ampliamente utilizado en rotación con maní, y soja, cultivo intensivo de nuestro país, demostró que las bacterias incrementan el crecimiento de esta plantas y además aporta $\mathrm{P}$ a sus tejidos y al sustrato de crecimiento en ensayos de microcosmo. Finalmente, la disponibilidad de la secuencia del genoma de dos de las cepas de la colección constituye una fuente potencial para profundizar en los aspectos de los mecanismos de solubilización de fosfato y la interacción de las bacterias con esta capacidad y plantas de interés agrícola.

Palabras clave: Fósforo, Ácido glucónico, Rizósfera. 